Hannelie Marx Archetypes of memory and amnesia

Hannelie Marx is a junior lecturer in the Department of Afrikaans at in South African soap opera

Email: hannelie.marx@up.ac.za

\title{
Archetypes of memory and amnesia in South African soap opera
}

This essay investigates the relationship between memory, or rather amnesia, in the South African context and soap opera. South Africa has only recently celebrated ten years of democracy and the past still affects the lives of its inhabitants. The country has undergone far-reaching shifts in its political, economic and cultural paradigms. These also manifest in the production of meaning in popular visual culture, and more particularly, in soap opera. South Africans remember in different ways - processes that are reflected in the narratives of local soap opera. The genre is popular and its viewers invariably identify with the extended story plots. Amnesia often comprises a large part of soap opera narrative. This essay suggests that archetypes and myths of amnesia may shed some light on these recurring themes of memory and amnesia. Initially, archetypes and myths pertaining to memory and amnesia are discussed, followed by the exploration of its manifestation in local soap opera. Key words: Soap opera, (South African), memory, amnesia, visual culture.

\footnotetext{
"Soap opera is commercial, but it is also a popular art form that has grown from the wellspring of culture and folk story and therefore appeals across time, cultures and even classes" (Williams, 1992: 2).

"Soapies are to the electronic age what oral tradition was to Homer and the novel was to Tolstoy: an elemental, even savage, connection with the blood in our collective veins" (Addison, 2004).
}

\section{Introduction}

In October 2001, during an episode of the popular South African soap opera Sewende Laan (Seventh Avenue), the character Wilmien makes the following remark to her employer:

I dreamt that she'd come back. That we'd be a family. Last night was just like when I was small. We ate. Laughed and joked (...) But what if they get together again? What about Christelle? He was so happy with her! If he hadn't lost his memory and I hadn't gone to Iceland they would have been married. 
In this quotation memory, or rather the loss of memory, has a significant influence on the development of the soap opera's story line. Baddeley (1999: 19) regarded "memory (...) (not as) a single unitary system, but rather an array of interacting systems, each capable of encoding or registering information, storing it, and making it available by retrieval." In the absence of memory an essential trait of human behaviour is missing: "we could not perceive adequately, learn from our past, understand the present, or plan the future" (Baddeley, 1999: 19). The question arises as to how remembering and forgetting are relevant to visual culture - that is, the "widespread, prevalent and current optically stimulating messages that is understood by the viewer" (Lester, 2000: 361)and in this case, soap opera. There are a number of reasons for the decision to focus on soap opera. Soap opera is an indisputably popular genre. For example, in South Africa soaps invariably occupy the top programmes slots of the country's five national television stations (Koenderman, 2004: 12). Furthermore, soaps often deal with everyday people and situations with whom the viewer identifies. Unlike the cinema, where the viewer's role becomes almost voyeuristic, television viewers are involved daily with the goings-on of their favourite soap opera. Most important for this paper is the predilection of this genre to employ recurring themes of memory and amnesia. Memory and amnesia are especially relevant to soap opera created within the South African context. South Africa has just celebrated ten years of democracy but its past still haunts its people. In the broader socio-political context of the country remembering and forgetting play a significant role. South Africans remember and forget in a variety of ways, processes that are apparent in local soap opera. How then do memory and amnesia manifest in contemporary South African soap opera?

I propose to take a closer look at the archetypal themes, fantasies, and myths that may shed light on the roots of this recurring amnesia theme. Elizabeth Wright (1989: 73) writes that Jung "sees in archetypal criticism a possibility for the scientific understanding of texts according to a classificatory system of modes, symbols, myth and genres. The strength of his approach is that his categories can be seen as exemplifying historically established patterns". The first section of the article will identify archetypal sources for memory, and in particular amnesia. Thereafter these primary influences will be discussed with regard to three South African soap opera, Sewende Laan (directed by Danie Odendaal), Egoli Place of gold (Franz Marx) and Isidingo - The need (Gray Hofmeyr). Since South African soap opera closely follow existing American examples 
inherent resemblances also pertain to the manifestation of amnesial myths and archetypes. Where relevant, reference will be made to appropriate American soap opera antecedents. Amnesia and soap opera will be explored with reference to its characters, narrative, and viewers.

\section{Archetypes of amnesia}

Although mythologies, as well as archetypes, may be fabricated, they are regarded as containing some truth. Stevens (1982: 36) observes that, "As long as human communities have existed they have devised mythologies (...), to account for the creation of the world and the origin of mankind. The mythology, once devised, was customarily handed down from one generation to the next as a corpus of factual knowledge". We are thus not dealing with explicit factual truths, but rather with an echo that shimmers throughout these devised stories. If an archetype "exemplifies historically established patterns" (Wright 1989: 73), these patterns will have to be identified within older texts first. Archetypes relevant to the specific theme of amnesia will be identified within ancient narratives, namely myths. Quite a number of myths and archetypes contain content relating to memory and amnesia.

The first archetypes supporting the importance of memory and amnesia are two essential archetypes identified by Carl Jung, namely the "shadow" and the "child". According to Jung the "shadow" is the personification of that part of human being, that psychic possibility, that denies something in us and projects it onto others. This connects with amnesia to the extent that a person may repress unwanted memories or character traits in their personal unconsciousness. The "child", on the other hand, suggests a pattern related to the hope and promise for new beginnings. When this archetype is viewed in context of amnesia it may suggest that amnesia becomes a kind of escapism, denying what happened in the past by forgetting, in order to make a new and clean start possible. This is relevant not only to individuals but also to the collective.

A distinction needs to be made between reality and memory. Based on classical Greek mythology, Hermes, together with the goddess Mnemosyne, represents the inherent difference between reality and memory. Mnemosyne is the goddess of memory. She owns all tales for without her power they could not exist. She has a capacity that computer memory cannot have namely, the capacity to lie: "Here Hermes is the ally of Mnemosyne. If a computer is programmed to lie, it can only say the wrong things or randomly reverse certain affirmations, which 
is very different from a falsehood inspired by Hermes, the patron of liars" (Paris, 1990: 137). Hermes does not only relate to Mnemosyne as far as memory is concerned. He is also associated with Hades. The headdress that Hades wears is of particular significance for Hermes. The cap has strange qualities: both Hades and Hermes wear it on different occasions. Athene puts on the hat to defeat Ares, and Perseus uses it to overcome the Gorgons. It makes the wearer invisible: "Evidently the explicit image of connection between Hermes and Hades is the headdress. Hades and Hermes share a certain style of covering their heads that both hides their thoughts and perceives hidden thoughts" (Hillman, 1979: 29). Hermes or Hades and their cap manifest in a variety of twentieth-century soap opera characters.

Hypnos is the Greek personification of sleep, brother of Thanatos (death), both children of Nyx (night). Both Hypnos and his brother live in the underworld. Awakening from sleep is almost like suffering some form of amnesia since it often happens that one is unable to remember the content of dreams. The river Lethe, also found in the mythic underworld, flows from the bottom of the cave where Hypnos has his abode. Lethe (Oblivion) is the river from which the dead and the spirits have to drink in order to forget their existence on earth. Figuratively, this river also flows through the narrative of contemporary soap opera, making characters forget in a variety of ways with a variety of outcomes.

The Oedipal myth also bears relevance to memory and amnesia. Oedipus is the son of Thebian king Laos and his wife Jokaste. The King gives up his son after the Oracle predicts that Oedipus will kill his father and marry his mother. Shepherds find the baby and he is raised by King Polubus. A grown Oedipus goes to Delphi to inquire about his future where the Oracle reveals what his father was told. On his way back to Thebe he struggles with, and eventually, kills a traveller who turns out to be his father. In Thebe Oedipus solves the sphinx's riddle that leads to its death. He becomes the hero of the Thebian people and unknowingly marries his mother. Later he learns the truth and pokes out his own eyes whilst his mother kills herself. Williams (1996: 45) writes, "to know is to have power", but to have knowledge can also be destructive, therefore to forget might amount to escapism. Thus with the Oedipal myth there is a continuing conflict between the advantages of knowing and the disadvantages of not knowing. In Oedipus' case the fact that he "knew" caused him not to know. The Oedipal myth is not only recognised in its love triangle, a key feature of soap 
opera, but also with regard to amnesia it appears in much more implicit ways.

\section{The Jung and the restless: archetypes reinvented Characters and narratives: archetypal manifestations}

Characters with amnesia often populate soap opera. The American soap opera, Days of Our Lives is an exemplar of amnesic myth in soap opera. At one stage or another, almost every character has suffered from amnesia or related symptoms. Characters like Marlena Evans, Roman Brady, Hope Brady, Sammy Brady, Carry Brady, John Black, and Austin Reed have all suffered memory loss at the hands of the evil Stephano de Mira. Stephano, the ultimate villain, in his many disguises, has all the distinctive qualities of a twentieth-century Mnemosyne. Like Mnemosyne, he is capable of randomly manipulating the truth, as well as the memory of these characters to suit his needs.

A study of South African soap opera reveals that soap opera is indeed transcultural. Archetypes of amnesia, comparable to those in American soap opera, manifest in similar, but also uniquely South African ways, in the narratives and characters of local soaps. Similar narratives and archetypes to those employed in American soap opera are also evident in Egoli-Place of Gold, the oldest South African soap opera, currently in its $14^{\text {th }}$ year (2004). The character Mitch is an example of the escapist amnesia fantasy at work. His temporary absence from the story line was supposedly due to amnesia. Mitch mysteriously disappears when his plane crashes and some months later is found begging at a traffic light, with no recollection of his past. Similarly, John Black, a character in Days of Our Lives suffers memory loss to such an extent that he remembers little or nothing of his past. Both of these characters changed dramatically during their amnesia. Mitch's begging at a traffic light, for instance, differs dramatically from his previous position as an executive. The way these characters have embodied the total opposites of who they really are reflect Jung's philosophy of the "shadow".

If it is true that "to know is to have power" (Williams, 1996: 45) the Oedipal myth may also be applicable in Mitch's case. Since he has no recollection of his immediate past Corine, one of the conniving female characters, almost convinced him that they are engaged to be married, which is untrue. In her case, as with Oedipus, knowledge is power until she is found out and the same knowledge turns destructive. Corine is in the position of power because of the knowledge she had until Mitch regains his memory and she does not have a hold over him any longer. 
Similarly, in Sewende Laan, a character named Leon sustained memory loss after a severe illness. He divorces his estranged wife and plans to marry Christelle. Amanda, his ex-wife, however, returns to be by his side in his hour of need. Due to his amnesia he cannot recall Christelle and falls in love again with Amanda. All this, as the quotation at the beginning of this paper suggests, was very traumatic for Leon and Amanda's daughter, Wilmien. Although she (Wilmien) is not suffering from amnesia she is the embodiment of the "child" archetype. In this case amnesia becomes the hope for a new beginning. Manuela Soares (in Williams, 1992: 53) authenticates the theory of the "child" archetype when she refers to amnesia in soaps as a "mask fantasy" that gives "characters, actors and (most important) audience a new life to live". The fact that knowledge, in this case, may prove to be destructive makes amnesia an escape mechanism of sorts. The amnesia fantasy might make Wilmien's lifelong dream, namely that of her parents getting back together, a reality, but she is torn between this fantasy and her respect for her father's fiancé, Christelle. Figuratively, the mythical river Lethe flows through this narrative, making Leon forget his past.

A quite common phenomenon in soap opera is the occurrence of good/bad twins, one the personification of virtue and the other the bearer of all the opposing bad qualities. Once again, the "shadow" archetype can be identified. Examples of good/bad twins in American soap opera are: Ben and Derek in Sunset Beach, Caroline Forrester and her twin Caren in Bold and the Beautiful, and Samantha and Eric Brady in Days of Our Lives. The good/bad twin scenario also manifests in Egoli where Kimberly, the bad twin, wants to avenge the death of her good twin sister, Jo-Anne Bennet. As with the American soap opera, each of the twins represents opposing moral values, "shadowing" one another.

Soap characters often romanticize the past, also indulging in a kind of amnesia. These scenes are characteristically structured through consecutive hazy flashbacks with love song tunes in the background. Mnemosyne can be recognized in this. Typically, characters in soap opera spend their lives trying to unite with their beloved ones, often facing problematic situations and hardly ever succeeding. Amidst all this turmoil however, they still find time to think back to seemingly idealistic times, conveniently forgetting the bad circumstances likely to be connected to these memories. This is clearly the intervention of Hermes and Mnemosyne, creating romanticized memories that contain a kernel of their original truth as exemplified in Sewende laan. On the Christmas or New Year holidays this soap opera, typically, will host 
lavish feasts with dancing and singing. At these gatherings all the characters interact, seemingly unaware of the conflicts that usually characterize their relationships. Amnesia does not only manifest in the narratives of soap opera however. Viewers are also influenced by these archetypes of amnesia.

\section{Amnesia, archetypes, fantasies, and the viewer}

One of the more persuasive reasons for the popularity of soap opera is the viewers' identification with these extended stories, where over long periods of time the audience develop relationships with the characters: "The complexity of the form is such that we are both invited to 'sit back and relish the spectacle' and drawn in to identify with characters as our emotional representatives" (Corner \& Harvey, 1996: 89). Sally Sussman, one of the chief writers of The Young and the Restless, says that to her Genoa City and the lives of her characters were so real that she "worried about their mortgages" and became "depressed" when Lauren Fenmore, whom she views as her alter ego, was held captive (Williams, 1992: 55). The fact that soap opera time runs parallel to "real" time contributes to this illusion of reality. Sewende Laan, like many other similar productions, for instance will consolidate its Christmas celebrations over the December holiday period. During the 2004 election in South Africa the writers of Egoli incorporated dialogue about voter registration and the subsequent election, thereby creating a familiar frame of reference and illusion of real life.

Soares, quoted earlier, suggests that amnesia in soap opera provides the hope of a new life. She explicitly includes the viewer when she refers to this "mask fantasy". It follows that not only soap opera plots and characters, as discussed above, are involved, but also the viewer. The viewer invariably regards television broadcasts or information in the mass media as "truth" or "reality". It serves thus not only as a source of memory but also as a source of authority. "Authority is clearly to be derived from the broadly communal nature of an experience, as if the truth, 'we all saw it', makes what was seen 'the truth'" (Burgin, 1996: 229). Burgin uses the excellent example of signs that accompany displays in stores reading "As seen on TV" supposedly rendering the product more real because it's electronic image was seen by millions of viewers. Due to this "soap opera reality" the bond between viewers and characters grow so strong that viewers feel "personally implicated in what happens in the lives of these characters" (Kilborn, 1992: 9). Burgin (1996: 232) observes that: 
[g]iven the paucity of real information provided by television (...) viewers may easily have contextualized the news images by more or less unselfconsciously inserting them into the memories of Hollywood war movies (...). Such narrative investments would come to fill in the intervening spaces between actually observed images.

The manifestation of amnesia is equally relevant to the narrative structure of soap opera and to the viewers. Viewers repress unwanted or unpleasant instances and fill these holes with scenes from soap opera. Burgin (1996: 229) follows Freud in proposing "the delusion owes its convincing power to the element of historical truth it inserts in the place of rejected reality".

Deborah Rogers (1992: 54) suggests a universal enthronement of the family in soap opera. Consider the soap All My Children that starts with pictures from a family album. Due to this prominence of the family in the genre, women viewers who are unsatisfied with real life sometimes use soap opera as a kind of substitute family: "It is almost as if - in an age where an increasing number of people have lost that sustaining sense of belonging to community (...), the possibility of regular involvement in the lives and affairs of a fictional group or community can be a very attractive one" (Kilborn, 1992: 9). Likewise, viewers do not make a distinction between the role an actor plays and the actual actor. Actors become defined by their roles. The fact that viewers confuse actors with the roles they play is not entirely surprising considering the lengths that producers go to make their characters credible. The Lauren Fenmore character, for example, moves freely between the storylines of The Young and the Restless and The Bold and the Beautiful creating the illusion that she is a "real person".

In some other instances actors appear on talk shows in their guise as soap opera characters. In Isidingo, a fictional television station, On TV, features a programme called "Live Time". Shortly thereafter the television channel on which the soap is flighted, introduced a similarly titled programme featuring the soap opera characters. No distinction is made between the actors and their characters. Other examples are soap opera related websites where viewers are encouraged to e-mail the characters rather than the actors. Situations or circumstances depicted in soap opera have similar implications. Viewers might reject certain "real" situations in order for more ideal situations depicted in soap opera. This is especially relevant in the South African context as will become clear in the next sub-section. 


\section{Collective amnesia and the South African soap opera}

Memory is often, incorrectly, regarded as an individual capacity. When acknowledging that a memory is a re-production or representation of reality tainted by personal beliefs it should not be forgotten that cultural and collective beliefs and traditions play an important role in any individual's life, albeit consciously or unconsciously. "Memory (...) is a socio-culturally constituted process in which the individual and the social are united" writes Middleton (1991: viii). Large numbers of people belonging to the same group or culture share ideas, concepts, and traditions, which are projected onto memories. Consequently, a popular or shared memory comes into being, made up of the governing views and customs of a specific group of people. Specific ideologies play a determining role in how a person remembers. Examples relevant to this study are the memories created during the apartheid period. A white South African no doubt remembers differently from a marginalised black South African. Williamson (1999: 34), for instance, writes about the anti-apartheid icon, Winnie Madikizela-Mandela, who was found guilty of the kidnapping of a teenager, saying that "her behaviour was indeed wrong, but we must embrace her as the dark side of all of us, the side injured by apartheid".

This does not change the fact that this is a prime example of the amazingly clear manifestation of the "shadow" archetype in the South African context. There have been wilful efforts to counter the ways in which different South African citizens remember in the form of the Truth and Reconciliation Commission (TRC). "The nation is fortunate that the TRC was brought into existence to provide an invaluable, if imperfect, vehicle for the past to be uncovered and for such divergent views to be aired" (Williamson, 1999: 34). Remembering clearly plays an integral role in the contemporary South African context. Forgetting, inevitably, is also important. David Koloane (1997:1) refers to such collective memory as well as amnesia. He criticises the determined attempts to cover past mistakes by forgetting them: "There is (...) a deliberate atmosphere of amnesia, and an undercurrent of denial regarding the immediate past". A large number of intellectuals, for instance the American critic, bell hooks, refer to this collective amnesia relating to apartheid and its repercussions. According to hooks (1996: 113) the very same master narratives that governed Modernism is still in tact: "Postmodern discourses are often exclusionary even as they call attention to, appropriate even, the experience of 'difference' and 'Otherness'.

Ivor Powell (1997: 52) on the other hand, believes that this collective 
amnesia is necessary. He believes that by forgetting the past a new and more democratic future becomes possible: "Not that nobody can remember how it was to live in a deeply racist society, but because nobody will remember. To do that would be to betray the foundations of the new society. There has to be a willed forgetfulness if we are to remember in a new South Africa". Whatever the case may be, and however the above opinions may differ, they all agree on one thing: the existence of this collective amnesia is tinged by ideology. This amnesia, in the form of affirmative action manifests in South African soap opera. Whereas black or other previously marginalized actors played mainly submissive roles, they now play more authoritative, substantial roles. Quite a few of the main storylines in a specific series of episodes centre on these characters.

This occurrence is, however, unique to South Africa. The appearance of such numbers of previously marginalized actors in soap opera is not an international phenomenon. Because of the current transformation ethos, and the pressure for racial and social transformation of institutions in South Africa, much more attention is paid to this. In Brazil, for instance, a black actor playing a lead role was only recently introduced into $\mathrm{Da}$ Cor do Pecado (The colour of sin), one of the major Brazilian soap operas. This is due to the specific socio-political climate in Brazil. According to Roberto Borges, (De Freitas, 2004: 15) although Brazil "has always been a deeply racist country (...) racism was never institutionalised in segregation or apartheid laws like in the US or South Africa". Another example of how the socio-political situation of a country influences the production of meaning in popular culture would be the USA. Consider the Bold and the Beautiful, which employs hardly any minority (or non-white) characters except when they play token roles such as domestic workers. Other soaps like Days of Our Lives use one or two token black couples. Karen Lindsey (1995: 333) writes that although more marginalized characters are starting to appear in American soap opera "this remains tokenism".

In contrast South African soap opera embodies some unique and inherently South African amnesia archetypes or myths. Whether this is because of collective guilt, as Koloane (1997: 1) would have it, or a collective effort to forget the past (Powell, 1997: 52) the demographic statistics are adding up, and are realistic in local soap opera. South African soaps distinguish between greater numbers of social stratifications than its American counterparts. Not only issues pertaining to race are braced, but also issues pertaining to class. Soap opera like Isidingo: The need, 
Backstage, and Generations, for instance, employ more coloured or black characters than white ones which is not typical in soap opera. In Sewende Laan, a soap aimed mainly at a white, middle class (Afrikaans speaking) audience, black and coloured actors play leading roles. In Isidingo: The need for instance, characters from all walks of life are depicted. Whilst some of the characters live in mansions, there are also prominent working class characters who are working in the mines. This difference in class is uncharacteristic in soap opera generally.

South Africa is in the process of constructing a new society with emerging ideologies. Because of this process of creating the new and purging the old a kind of cultural amnesia occurs. The scenarios depicted in these soaps are very real. Whereas a South Africa, still holding on to an ideology of apartheid and not suffering from amnesia, would have depicted largely white South Africans this is not the case any longer. Soaps currently deal to a much greater extent, and much more explicitly with the fundamental social and political changes that South Africa have undergone and are still undergoing. In Isidingo for instance, a multicultural marriage is depicted. This wedding and the relationship that preceded it, was the first intercultural relationship to be screened on local television. The white female character, Phillipa de Villiers, and the leading black male character, Derek Nyati, had two wedding ceremonies, the one indigenous and the other Western. Initially, viewers reacted negatively towards the relationship (Toffoli, 1999: 44) but when the characters broke up fan mail streamed in demanding that they should get back together again. Several other intercultural relationships followed in similar soaps.

While interracial relationships exist in reality, it does not happen often and when it does, it may still be frowned upon. Because of this process of constructing the new, and ultimately a new South Africa, one thus finds a type of utopian society depicted in these soap opera. Different racial groups interact in a way that should be the ultimate goal for the country, but is hardly the case. It seems that the "child" archetype can be identified in viewers and writers alike since they all suffer from amnesia concerning the past (and the less than ideal present) of South Africa.

One can hardly watch a South African soap opera without stumbling across some amnesia theme, perhaps reflective of the amnesia that makes up an integral part of the present cultural situation. This inevitably involves not only actors and viewers but also writers in the narrative structures of local soap opera. 


\section{Conclusion}

Logically it seems unlikely that in the contemporary environment of previously unsurpassed technological and scientific progress, something as ancient as myths and archetypes can prove to aid the continuous human need for comprehension. Granted, it could be argued that some other better or more contemporary systems of comprehension must have evolved. Upon reading the title of this essay it might have been viable to argue that searching for a connection between twentyfirst century soap opera, the consumer, South Africa and age old archetypes seems far-fetched. Nonetheless, when one considers the large amount of similarities uncovered, one has to admit that the psychoanalytical method of analysis still merits such research.

Mnemosyne, or goddess-memory, still manifests today, maybe even more so than in the past. In the way all contemporary occurrences serve as subject matter for that which is created by humans, so too does this obsession with memory, or more specifically, amnesia. This is also the case with soap opera. I have identified a number of cases where soap opera characters suffer from amnesia in different soap opera to prove this point substantially.

In South Africa themes of memory and amnesia carry even more weight. Since the country has only recently emerged from apartheid, South Africans are currently dealing extensively with their past. One of the ways in which this struggle has manifested is in a type of cultural amnesia. In the process of constructing a new South African ideology and focussing on the present and the future, the past is often "forgotten" or neglected. South Africa's struggle and the country as a whole might be personified in the "child" archetype where the hope for new beginnings overshadows the past. This also finds representation in local soap opera narratives.

As Huyssen (1995) so correctly argues, what is viewed on television has reached the status of defining the "real". In the twentieth-century consumers' personal lives become increasingly interweaved with massconsumer and visual culture. This overlapping of mass culture and the personal happens to such an extent that fictional characters from television or films enter the personal domain. A prime example of these characters invading domestic lives is that of the soaps. Soap opera as a genre lends itself more readily to this infiltration into the private domain because of the continuous exposure viewers get to the archetypal characters and situations with which they can associate themselves. It becomes another "reality" or dimension, or a from of escapism, an amne- 
sia fantasy, as it were. Soaps serve as sources for filling private spaces with consumer images. The significance of this is that memory issues therefore not only manifest in fictional narratives such as soap opera, but also in "real life". By indulging in amnesia, soaps thus actively take part in the construction of a new South Africa, and ultimately play a role in affecting social change. It becomes a kind of xenogamy and draws from the lives of consumers for inspiration and vice versa.

\section{Acknowledgements}

I wish to express my thanks to Amanda du Preez for supervising the study on which this essay is based. My appreciation also goes to the anonymous readers of Tydskrif vir letterkunde for their helpful comments and suggestions. The title of a subsection in this essay - "The Jung and the restless" - was influenced by John McManamy's website Macman's Depression and Bipolar Web (Macman, 2001).

\section{Bibliography}

Addison, G. 2004. [O]. Soapies-R-Us. [Dmg] Mail and Guardian Online HTML Edition. Accessed: 6 May.

Allen, R.C. 1992. Channels of Discourse, Reassembled. Television and Contemporary Criticism. London: University of North Carolina Press.

Anderson, W. T. 1996. The Fontana Postmodern Reader. Great Britain: Fontana Press.

Baddeley, A. D. 1999. Essentials of Human Memory. United Kingdom: Psychology Press.

Barthes, R. 1977. S/Z. New York: Hill \& Wang.

Blodgett-McDeavitt, J.J. 1997. [O]. Order of the Red Grail Nebraska Community: An Excursion into the Mind of C.G. Jung, Father of Analytic Psychotherapy. http://redgrail.freeservers.com/papers/ jung.html. Accessed: 3 September 2001.

Burgin, V. 1996. In/Different Spaces. Place and Memory in Visual Culture. California: University of California Press.

Cantor, M.G. \& Pingree, S. 1983. The Soap Opera. London: Sage Publications.

Cassiman, B. Ramael, G. \& Vande Veire, F. 1993. The Sublime Void. On the Memory of the Imagination. Antwerp: Ludion.

Corner, J. \& Harvey, S (Eds.). 1996. Television Times. A Reader. United States: St Martin's Press.

Cushman, D. 2001. Dustin's Days of Our Lives Page. http://soapoparefan.com/days/ [O] Accessed: 1 November 2001.

De Freitas, F. 2004. Pride and prejudice. Sunday Times, 13 June, 15.

De Swardt, L. 2000 Diva van Harte, Rooi rose, April, 16-18. 2001. Lag is kos vir die siel, Rooi rose, Oktober, 20-23.

Dines, G. \& Humez, J. (Eds). 1995. Gender, Race and Class in Media. A Text Reader. London: Sage.

Enwezor, O. (Ed). 1997. Trade Roots. History and Geography. Singapore: SNP Printers.

Fish, JL. 2000. [O] Days of Our Lives. Like sands through... http://clubs.yahoo.com/clubs/daysofourlives. Accessed: 4 November 2001.

Frankel, D. \& Franzen E. (Eds). 1999. Liberated Voice: Contemporary Art from South Africa. Belgium: Snoeck-Ducaju \& Zoom.

Frentz, S. (Ed). 1992. Staying Tuned. Contemporary Soap Opera Criticism. Ohio: Bowling Green State University Press.

hooks, b. 1996. Postmodern Blackness. In The Fontana Postmodern Reader. Walter Truett Anderson (ed.). Great Britian: Fontana Press.

Hillman, J. 1985. Anima. Texas: Spring Publications.

1979. The Dream and the Underworld. London: Harper \& Row.

1999. The Force of Character and the Lasting Life. New York: Random House.

Huyssen, A. 1995. Twilight Memories. Marking Time in a Culture of Amnesia. New York: Routledge.

Jacobi, J. 1942. The Psychology of C.G. Jung. London: Routledge \& Kegan Paul. 
Kilborn, R. 1992. Television Soaps. London: B.T. Batsford Ltd.

Koloane, D. 1997. Walking the Tightrope, in Trade Roots. History and Geography, Okwui Enwezor (ed.). Singapore: SNP Printing.

Koenderman, T. 2004. Tony Koenderman's AdReview. South African Media Facts. Johannesburg: OMD.

Kühn. W. 2001a. Bianca se mooiste dag...op TV, Huisgenoot, 7 Junie, 12-14.

2001b. Tawwe tienie met die sagte hart, Huisgenoot, 9 Augustus, 16-18.

. 2001c. Vir Days se Billie: nuwe dae, nuwe dinge, Huisgenoot, 4 Oktober, 128-130.

Lester, P.M. 2000. Visual Communication. Images with Messages. United States: West Group.

Lindsay, K. 1995. "Race, Sexuality and Class in Soapland", in Gender, race and class in media. A text reader, Gail Dines \& Jean Humez (eds.). London: Sage.

Macman, J. 2001. [O]. The Jung and the Restless. http://www.mcmanweb.com/article-81.htm. Accessed: 1 November 2001.

Marc, D. \& Thompson, R.J. 1992. Prime Time, Prime Movers. Canada: Little Brown and Company.

Mattes, M. 1996. [O]. Days of Our Lives. http://daysofourlives.simplenet.com/. Accessed: 1 November 2001.

Middleton, D. \& Edwards, D. (Eds.). 1991. Collective Remembering. London: Sage Publications.

Newcomb, H. (Ed.). 1994. Television. The Critical View. New York: Oxford University Press.

Parada, C. 1997. [O] Greek Mythology Link. http://has.brown.edu/ maicar/Abstractions.html. Accessed: 1 November 2001.

Paris, G. 1990. Pagan Grace: Dionysos, Hermes, and Goddess Memory in Daily Life. United States of America: Spring Publications.

Powell, I. 1997. The Pale and Beyond: Rethinking Art in A Reconstructed Society, in Trade Roots. History and Geography, Okwui Enwezor (ed.). Singapore: SNP Printing.

Rogers, D.D. 1992. The Afternoons of our Lives, in Staying Tuned. Contemporary Soap Opera Criticism, Suzanne Frentz (ed.). Ohio: Bowling Green State University Press.

Samuel, S. 2001, Met Sewende Laan langs, Beeld Plus, 8 September, 4.

Shea, MJ. 2000. [O] Somatic Psychology. Body As Shadow. http://www.sheacranial.com/publications/ papers/paper_bas.htm. Accessed: 4 September 2001.

Stevens, A. 1982. Archetype. London: Routledge.

Stewart, M. 2001. [O] Soap central. http://www.soapcentral.com/soapcentral/index.php. Accessed: 1 November 2001.

Toffoli, H.R. 1999. Soap for the nation, Style, December-January, 44-49.

Van Reeth, A. 1994. Ensiklopedie van die Mitologie. Kaapstad: Vlaeberg.

Wright, E. 1989. Psychoanalytic Criticism: Theory in Practice. London: Routledge.

Williams, C.T. 1992. It's Time for My Story. Soap Opera sources, Structure, and Response. London: Preager.

Wiliamson, S. 1999. Looking back, looking forward: An overview of South African art, in Liberated Voices: Contemporary Art from South Africa David Frankel \& Elizabeth Franzen (eds.). Belgium: Snoeck-Ducaju \& Zoom. 